\begin{tabular}{|c|c|c|}
\hline \multirow[t]{3}{*}{ BENTHAM OPEN } & $\begin{array}{c}\text { Open Cybernetics \& Sys } \\
\text { Journal }\end{array}$ & $\begin{array}{l}\text { The Open } \\
\text { Cybernetics \& Systemics } \\
\text { lournal }\end{array}$ \\
\hline & Content list available at: www.benthamopen.com/TOCSJ/ & 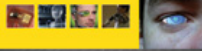 \\
\hline & DOI: $10.2174 / 1874110 X 01610010069$ & \\
\hline
\end{tabular}

\title{
Retraction Notice: Sports Food Safety Supervision Based on AHP and Interval Fuzzy TOPSIS
}

Huixia Sun

Huanghe Science and Technology College, China

\section{RETRACTION}

The Publisher and Editor have retracted this article [1] in accordance with good ethical practices. After thorough investigations we believe that the peer review process was compromised. The article was published online on 08-10-2015.

\section{REFERENCE}

[1] H. Sun, "Sports Food Safety Supervision Based on AHP and Interval Fuzzy TOPSIS", Open Cybern. Syst. J., vol. 9, pp. 1905-1910, 2015.

\section{(C) Huixia Sun; Licensee Bentham Open.}

This is an open access article licensed under the terms of the Creative Commons Attribution-Non-Commercial 4.0 International Public License (CC BY-NC 4.0) (https://creativecommons.org/licenses/by-nc/4.0/legalcode), which permits unrestricted, non-commercial use, distribution and reproduction in any medium, provided the work is properly cited.

* Address correspondence to these authors at the Huanghe Science and Technology College, China; Tel: +358-6-3247476; Fax: +358-6-3247457; Email: hunter2011@foxmail.com 